\title{
Uji Efektivitas Ekstrak Daun Kirinyuh (Chromolaena Odorata \\ (L.) R. M. King Dan H. Rob) Sebagai Herbisida Alami Terhadap Perkecambahan Biji Kacang Hijau (Vigna Radiata (L.) R.Wilczek) Dan Biji Karuilei (Mimosa Invisa Mart. ex Colla)
}

\author{
The Effectiveness test of Kirinyuh (Chromolaena odorata (L.) \\ R.M.King dan H.Rob) leaf extract as natural herbicides to seed \\ germination of mung beans (Vigna radiata (L.) R.Wilczek) and \\ karuilei (Mimosa invisa Mart. ex Colla)
}

\author{
Dian Frastika*), Ramadhanil Pitopang dan I Nengah Suwastika
}

Jurusan Biologi FMIPA, Universitas Tadulako

Kampus Bumi Tadulako Jl. Soekarno-Hatta Km.9 Palu, Sulawesi Tengah 94118

\begin{abstract}
The research about effectiveness test of kirinyuh's leaf (Chromolaena odorata (L.) RMKing \& H.Rob) as natural herbicides on green beans seed germination (Vigna radiata (L.) R.Wilczek) and seed karuilei of Mimosa invisa Mart. Ex Colla were conducted in July until September 2016, at the Biotechnology Laboratory of Biology Department Faculty of Mathematics and Natural Sciences, Tadulako University of Palu. This research was prepared based on Completely Random Design (CRD) model, consisted of 6 treatments and 3 repetitions with concentration extract as treatment, i.e. $\mathrm{P} 0=0 \% \mathrm{P} 1=15 \% \mathrm{P} 2=20 \% \mathrm{P} 3=$ $25 \% \mathrm{P} 4=30 \% \mathrm{P} 5=35 \%$. Observation variables were on seed viability (percentage of germination), germination rate, hypocotyl length and fresh weight. The results showed that giving of kirinyuh leaf extract C.odorata had an effect on inhibiting germination of green beans $V$. radiata and karuilei of Mimosa invisa. The germination inhibition of $M$. Invisa seeds and green beans ( $V$. radiata) started from a concentration of $15 \%$ to $35 \%$. The results of phytochemical screening of $C$. Odorata leaves show only "positive" will be good containing secondary metabolite compounds, such as saponins, tannins, flavonoids, alkaloids and phenolic.
\end{abstract}

Keywords: leaf extract Chromolaena odorata, germination,Vigna radiata and Mimosa Invisa

\section{ABSTRAK}

Penelitian uji efektivitas daun kirinyuh (chromolaena odorata (L.) R. M. King \& H.Rob) sebagai herbisida alami terhadap perkecambahan biji kacang hijau (Vigna radiata (L.) R. Wilczek) dan biji karuilei (Mimosa invisa Mart. Ex Colla) dilaksanakan pada bulan Juli sampai September 2016, di Laboratorium Bioteknologi Jurusan Biologi Fakultas Matematika dan Ilmu Pengetahuan Alam, Universitas Tadulako. Penelitian ini disusun berdasarkan model Rancangan Acak Lengkap (RAL) terdiri dari 6 perlakuan dan 3 kali pengulangan dengan konsentrasi ekstrak P0 $=0 \% \mathrm{P} 1=15 \% \mathrm{P} 2=20 \% \mathrm{P} 3=25 \% \mathrm{P} 4=30 \%$ 
P5 $=35 \%$. Variabel pengamatan meliputi daya kecambah (persentase perkecambahan), laju perkecambahan, panjang hipokotil dan berat basah. Hasil penelitian ini menunjukan bahwa pemberian ekstrak daun kirinyuh Chromolaena odorata berpengaruh dalam menghambat perkecambahan biji kacang hijau Vigna radiata dan biji karuilei Mimosa invisa. Pengambatan perkecambahan biji karuilei $M$. invisa dan kacang hijau $V$. radiata dimulai dari konsentrasi $15 \%$ sampai $35 \%$. Hasil skrining fitokimia daun C. Odorata positif mengandung senyawa metabolit sekunder, yaitu saponin, tanin, flafonoid, alkaloid dan fenilok.

\section{Kata kunci: Ekstrak daun, Chromolaena odorata, germination, Vigna radiata and Mimosa Invisa.}

\section{LATAR BELAKANG}

Keberadaan gulma pada arealtanaman budidaya dapat menimbulkan kerugian baik dari segi kuantitas maupun kualitas produksi. Metode pengendalian gulma yang dapat dilakukan di antaranya pengendalian dengan upaya preventif, mekanis/fisik, kultur teknis, pengendalian dengan upaya memanfaatkannya, dan pengendalian secara kimiawi (herbisida). Pada saat ini banyak digunakan herbisida sintetis, yang dapat menimbulkan dampak negatif kerusakan lingkungan (Rukmana, 1999).

Herbisida sintetis secara tidak langsung mempunyai banyak dampak negatif. Pengaruh negatif yang ditimbulkan oleh herbisida sintetik adalah sifatnya tidak selektif, pencemaran lingkungan, meninggalkan residu pada produk pertanian, matinya beberapa musuh alami dan merusak alam baik untuk sementara maupun secara permanen, penurunan kadar organik tanah (Susanti, dkk 2014).

Banyaknya dampak negatif yang ditimbulkan akibat penggunaan pestisida sintetik antara lain pencemaran lingkungan, merusak alam baik untuk sementara maupun secara permanen, serta penurunan kadar organik tanah. mendorong perlunya mencari alternatif pengendalian gulma yang ramah lingkungan atau berwawasan lingkungan merupakan salah satu alternatif yang di gunakan. Upaya tersebut di lakukan dengan menggali potensi senyawa kimia yang berasal dari tumbuhan (allelopati) yang dapat di manfaatkan sebagai herbisida alami. Tumbuhan mengandung banyak bahan kimia yang merupakan metabolit sekunder dan digunakan oleh tumbuhan sebagai alat pertahanan dari serangan organisme pengganggu. Herbisida alami dari tumbuhan dapat digunakan sebagai herbisida yang ramah lingkungan karena tidak mengandung bahan berbahaya, tidak meninggalkan residu atau mencemari tanah (Asmaliyah dkk., 2010).

Kirinyuh (Chromolaena odorata (L.) merupakan tumbuhan yang bersifat allelopati yang dapat dijadikan herbisida alami.Kirinyuh sangat cepat tumbuh dan berkembang biak. Karena cepatnya 
perkembangbiakan dan pertumbuhannya, tumbuhan ini juga membentuk komunitas yang rapat sehingga dapat menghalangi tumbuhnya tumbuhan lain melalui persaingan. Selain itu kirinyuh mempunyai alelopati yang mampu menunda perkecambahan. Berbagai senyawa yang bersifat alelopati berupa minyak atsiri, Flavonoid, Alkaloid, Fenolik, Saponin, Tanin. Senyawa tersebut terkandung dalam berbagai jenis tumbuhan termasuk tumbuhan kirinyuh

(Chromolaena odorata (L.) (Sunarwidi, 1986).

Herbisida alami merupakan hasil dari tumbuhan yang memiliki potensi sebagai herbisida dengan prinsip allelokemi atau senyawa yang terdapat pada proses pelepasan allelopati yang di hasilkan oleh tumbuhan tersebut. Penggunaan herbisida alami juga merupakan produk alam dari tumbuhan seperti daun, bunga, buah, biji, kulit, dan batang yang mempunyai kelompok metabolit sekunder atau senyawa bioaktif. Herbisida alami di anggap ramah lingkungan karena tidak mengandung bahan berbahaya, tidak meninggalkan residu atau mencemari tanah sehingga aman bagi manusiamaupun hewan dan telah banyak digunakan dalam sistem pertanian organik. Kemampuan alelopati yang dihasilkan tanaman dapat dimanfaatkan sebagai herbisida alami dalam sistem agrikultur yang kemampuannya sama dengan herbisida sintetik (Apriyana dkk., 2012).

Tumbuhan yang di ujikan dalam penggunaan herbisida alami yaitu tanaman Budidaya Kacang hijau (Vigna radiata (L.) R.Wilczek ). Kacang hijau (Vigna radiata (L.) R.Wilczek ) merupakan salah satu tanaman yang cukup penting di indonesia. Karena kacang hijau banyak mengandung vitamin, terutama vitamin B1 yang merupakan zat tambahan berharga bagi rakyat yang relatif kurang vitamin. Manfaat kacang hijau sebenarnya bukan hanya sebagai penghasil bahan makanan juga memiliki kelebihan secara agronomis dan ekonomis. Tanaman kacang hijau juga dapat mengalami penurunan produksi akibat gulma atau tanaman pengganggu yang tumbuh di sekitarnya gulma yang biasanya tumbuh ialah Mimosa invisa Mart. Ex Colla (Suprapto, 1993).

Berdasarkan uraian di atas, maka di lakukan pengujian ekstrak kirinyuh (Chromolaena odorata (L.) sebagai herbisida alami terhadap perkecambahan kacang hijau (Vigna radiata (L.) dan karuilei Mimosa invisa. Hal ini di sebabkan karena karuilei (Mimosa invisa) menjadi pesaing dalam pengambilan unsur hara dan sinar matahari. 


\section{BAHAN DAN METODE}

Bahan

Bahan-bahan yang digunakan adalah Biji kacang hijau, Mimosa invisa,daun kirinyuh, aquades, kertas label, etanol 96 $\%$, kertas saring, Bayclin 1\%, Asam sulfat, serbuk $\mathrm{Mg}, \mathrm{HCl} 2 \mathrm{M}$, pereaksi Wagner, $\mathrm{FeCl}_{3} 1 \%$, serbuk $\mathrm{NaCl}$.

\section{Metode Penelitian}

Penelitian ini menggunakan metode Eksperimental, diujikan terhadap kecambah $V$. radiata dan $M$. invisa dengan masingmasing konsentrasi ekstrak yang sama. Penelitian disusun berdasarkan model Rancangan Acak Lengkap (RAL) terdiri dari 6 perlakuan, tiap perlakuan diulangi sebanyak 3 kali ulangan. Susunan perlakuannya yaitu $\mathrm{P}_{0}, \mathrm{P}_{1}, \mathrm{P}_{2}, \mathrm{P}_{3}, \mathrm{P}_{4}, \mathrm{P}_{5}$ dengan konsentrasi ekstrak yang terdiri dari 5 seri konsentrasi yaitu $0 \%, 15 \%, 20 \%$, $25 \%, 30 \%$ dan $35 \%$.

a. Pengambilan sampel daun tumbuhan Chromolaena odorata L, biji Vigna radiata dan biji Mimosa invisa.

Pengambilan daun tumbuhan $C$. odorata L, biji Vigna radiata dan biji Mimosa invisa dilakukan di tempat berbeda, yaitu untuk pengambilan sampel daun tumbuhan $C$. odorata Diperoleh di kelurahan TONDO PALU kemudian pengambilan sampel biji $M$. invisa diperoleh di kabupaten SIGI, DOLO dan biji $V$. radiata diperoleh di kelurahan TONDO.

\section{b. Ekstraksi sampel daun tumbuhan Chromolaena odorata $\mathbf{L}$}

Metode ekstraksi yang digunakan yaitu menggunakan Metode Maserasi. Daun $C$. odorata dibersihkan terlebih dahulu (sortasi basah) kemudian ditimbang untuk mengetahui berat basah dari simplisia tersebut, kemudian dicuci dengan air mengalir sampai bersih dan dirajang sampai berukuran kecil dan kemudian ditimbang sehingga diperoleh berat basah sebesar $7500 \mathrm{~g}$ Hasil rajangan daun $C$. odorata dikeringkan dengan menggunakan oven pada suhu $40^{\circ} \mathrm{C}$ selama \pm 8 jam, tujuannya yaitu untuk mengurangi kandungan air dari simplisia sehingga mencegah tumbuhnya jamur. Setelah proses pengeringan, daun kemudian ditimbang sehingga diperoleh berat kering sebesar $5700 \mathrm{~g}$.

Daun yang telah kering kemudian dihaluskan menggunakan blender dan diayak dengan mess 40 sehingga dihasilkan struktur daun yang sangat halus, setelah itu simplisia ditimbang kembali sehingga diperoleh hasil simplisia sebesar $5000 \mathrm{~g}$.

Hasil ayakan simplisia tersebut kemudian direndam menggunakan pelarut etanol $96 \%$ dengan volume pelarut sebanyak 1,5 liter dan didiamkan selama 5 hari. Hasil rendamani disaring menggunakan kertas saring dan 
dilakukan pemisahan antara zat pelarut dan senyawa aktif hasil ekstraksi dengan menggunakan alat rotari evaporator (Depkes RI, 2000). sehingga yang dihasilkan ekstrak kental sebesar $145 \mathrm{~g}$.

\section{c. Skrining Fitokimia}

1. Saponin

Ekstrak sebanyak $0,5 \quad \mathrm{~g}$ dimasukkan dalam tabung reaksi, ditambahkan air dan dipanaskan di water bath. busa yang stabil menunjukkan kandungan saponin (Ramyashree et al., 2012).

\section{Tanin}

Ekstrak sebanyak 0,5 g diaduk dengan $10 \mathrm{ml}$ aquades, disaring dan ditambahkan reagen $\mathrm{FeCl}_{3}$. warna hijau/biru kehitaman menunjukkan kandungan tanin (Ramyashree et al., 2012).

\section{Flavonoid}

Ekstrak sebanyak 0,5 g dicampur dengan aquades dan dilarutkan dengan serbuk $\mathrm{Mg}$ sebanyak $0,1 \mathrm{mg}$, lalu ditambahkan $\mathrm{HCl}$ sampai berubah warna. Apabila terbentuk warna orange, merah dan merah bata atau kuning berarti menandakan kandungan flavonoid (Pakaya, 2015).

4. Alkaloid

Ekstrak sebanyak 0,5 g dimasukkan ke dalam gelas piala, ditambah dengan $\mathrm{HCl} 2 \mathrm{M}$ dan dipanaskan di atas penangas air sambil diaduk, kemudian didinginkan hingga suhu kamar. $\mathrm{NaCl}$ serbuk ditambahkan, diaduk dan disaring, kemudian filtrat ditambah HCL 2M setelah itu ditambahkan pereaksi Wagner sebanyak . Hasil positif jika terbentuk warna coklat (Resmi, 2011)

5. Fenolik

Ekstrak sebanyak 0,5 gram ditambahkan larutan $\mathrm{FeCl}_{3} 1 \%$, positif adanya fenolik jika terjadi perubahan warna hijau, merah ungu, biru/ hitam (Resmi, 2011).

\section{d. Perlakuan Pendahuluan biji Mimosa invisa}

Pada penelitian ini perlakuan pendahuluan biji juga diperlukan karena, biji M. Invisa cukup keras atau mempunyai sifat dormansi. Perlakuan pendahuluan biji $M$. Invisa pada penelitian dilakukan dengan menyeleksi biji dengan cara merendam biji dengan air, kemudian diambil biji yang tenggelam. Setelah itu memilih biji yang memiliki bentuk dan ukuran yang sempurna (tidak cacat atau keriput) dan dikeringkan.

Prosses selanjutnya perendaman biji ke dalam larutan Asam sulfat $95 \%$ yang telah di encerkan dengan aquades selama 2-5 menit kemudian dicuci dengan akuades. 


\section{e. Uji Daya Hambat Kecambah}

Langkah-langkah yang dilakukan

UDHK ini yaitu sebagai berikut:

1. Kertas saring (3 lembar) diletakkan pada cawan petri.

2. Kertas saring dibasahi sebanyak $10 \mathrm{ml}$ sampai $20 \mathrm{ml}$ ekstrak daun Chromolaena odorata sesuai dengan perlakuan konsentrasi $0 \%, 15 \%, 20 \%$, $25 \%, 30 \%$, dan $35 \%$ dibiarkan sampai meresap.

3. Biji $V$. radiata dan $M$. invisa ditanam di atas lembar kertas saring dengan pinset sebanyak 5 butir pada cawan yang berbeda.

4. Biji yang telah ditanam di cawan petri kemudian diberi ekstrak daun C.odorata sesuai dengan perlakuan konsentrasi masing-masing $10 \mathrm{ml}$.

5. Kelembaban media tumbuh dijaga selama penelitian berlangsung dengan pemberian aquades sesuai dengan perlakuan

6. Disimpan di tempat yang terkena cahaya, dipelihara pada suhu $28^{\circ} \mathrm{C}$, dan penyinaran selama 12 jam.

\section{f. Variabel Pengamatan}

Adapun variabel yang diamati dalam penelitian ini meliputi :

\section{Daya Kecambah}

Menurut Sutopo (2004), pengamatan dilakukan pada hari ke15 dengan menghitung kecambah normal. Menggunakan rumus sebagai berikut :

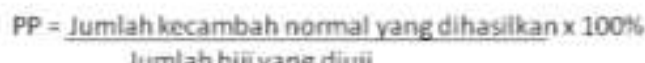

\section{Waktu munculnya kecambah} (Hari)

Menurut Sutopo (2004) pengamatan dilakukan setiap hari setelah tanam dengan menghitung lama waktu munculnya kecambah dalam satuan hari setelah tanam. Menggunakan rumus sebagai berikut:

$\Sigma=\frac{\mathrm{N}_{1} \mathrm{~T}_{1}+\mathrm{N}_{2} \mathrm{~T}_{2}+\ldots \ldots \ldots \mathrm{N}_{x} \mathrm{~T}_{x}}{\text { Total Biji Yang Berkecambah }}$

Ket:

$\mathrm{N}=$ jumlah kecambah yang muncul pada waktu tertentu

$\mathrm{T}=$ jumlah waktu antara awal suatu pengujian sampai dengan akhir dari interval tertentu.

$\mathrm{PP}=$ Presentase perkecambahan

$\Sigma=$ Rata-rata hari munculnya kecambah

\section{Pengukuran Panjang Hipokotil}

Pengukuran panjang hipokotil dimulai dari leher akar sampai dengan pangkal kotiledon dengan menggunakan penggaris dilakukan 3 kali ulangan kemudian dihitung rataratanya.

\section{Berat Basah Kecambah}

Pengukuran berat basah dilakukan pada hari ke-15 dengan menggunakan neraca analitik.

\section{g. Analisis Data}

Hasil pengamatan dari setiap parameter pengamatan dianalisis menggunakan SPSS (Statistical Product Service Solution) two way ANOVA 
(Analysis Of Varian) dan jika berbeda nyata, maka di lakukan uji lanjut berganda DMRT (Duncan'sMultiple Range Test) dan data standar deviasi menggunakan software (Microsoft Office Excel) 2007 dalam bentuk grafik (Tukey, 1953).

\section{HASIL}

\section{Skrining fitokimia}

Uji skrining fitokimia menunjukkan bahwa ekstrak daun Chromolaena odorata $\mathrm{L}$ positif mengandung senyawa metabolit sekunder ( Tabel 1).

\section{Daya Kecambah (\%)}

Berdasarkan hasil analisis secara statistik,menunjukan hasil daya kecambah yang tidak berbeda nyata $(\mathrm{P}=<0,05)$ bahwa pemberian ekstrak dengan konsentrasi yang berbeda akan mempengaruhi daya kecambah pada masing-masing perlakuan. Daya kecambah tertinggi pada tumbuhan kacang hijau (Vigna radiata) di peroleh pada pemberian P0 konsentrasi $0 \%$ ( air) berturut- turut sampai yang terendah dari konsentrasi 35 \% sampai $15 \%$ dan biji (Mimosa invisa) di peroleh pada pemberian P0 konsentrasi $0 \%$ (air) sebagai kontrol, berturut-turut sampai yang terendah dari konsentrasi $25 \%$ sampai $15 \%$. (Gambar 1).
Tabel 1. Hasil Skrining Fitokimia

\begin{tabular}{|c|c|}
\hline $\begin{array}{c}\text { Senyawa Metabolit } \\
\text { Sekunder }\end{array}$ & $\begin{array}{c}\text { Hasil } \\
\text { Positif/negative }\end{array}$ \\
\hline Saponin & + \\
\hline Tanin & + \\
\hline Flavonoid & + \\
\hline Alkaloid & + \\
\hline Fenolik & + \\
\hline
\end{tabular}

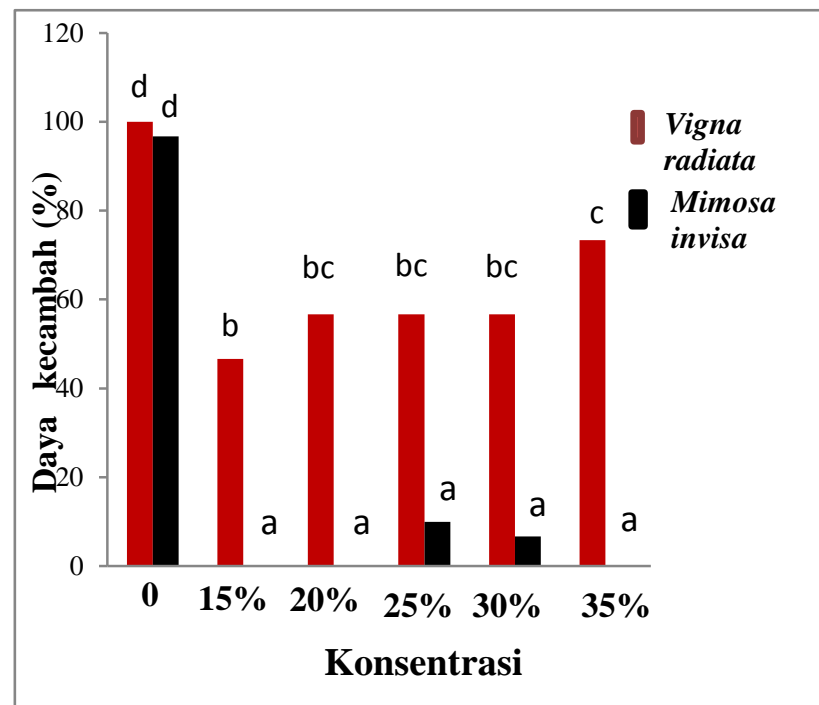

Gambar 1 Grafik data daya kecambah V.radiata dan M.invisa 15 hari setelah tanam dengan konsentrasi ekstrak yang diberikan yaitu $0 \%$ $\left(\mathrm{P}_{0}\right), 15 \%\left(\mathrm{P}_{1}\right), 20 \%\left(\mathrm{P}_{2}\right), 50 \%\left(\mathrm{P}_{3}\right)$, $30 \%\left(\mathrm{P}_{4}\right)$ dan $35 \%\left(\mathrm{P}_{5}\right)$. Nilai yang ditunjukkan pada grafik adalah nilai rata-rata \pm standar deviasi.yang diikuti oleh huruf yang sama menunjukkan tidak berbeda nyata pada taraf uji $5 \%(P \geq 0,05)$.

\section{Hari munculnya kecambah (Hari)}

Berdasarkan hasil analisis hari munculnya kecambah secara statistik, menunujukan hasil yang tidak berbeda nyata $(\mathrm{P}=<0,05)$ bahwa pemberian ekstrak yang berbeda konsentrasinya dapat mempengaruhi laju perkecambahan masing-masing perlakuan. Hari munculnya kecambah tertinggi pada tumbuhan kacang 
hijau (Vigna radiata) diperoleh pada pemberian P0 konsentrasi $0 \%$,berturutturut yang terendah dari konsentrasi 35\% sampai $15 \%$ dan biji (Mimosa invisa) diperoleh pada pemberian P0 konsentrasi 0 $\%$ (air) sebagai kontrol, berturutturut yang terendah pada pemberian konsentrasi $30 \%$ sampai $15 \%$ ( Gambar 2).

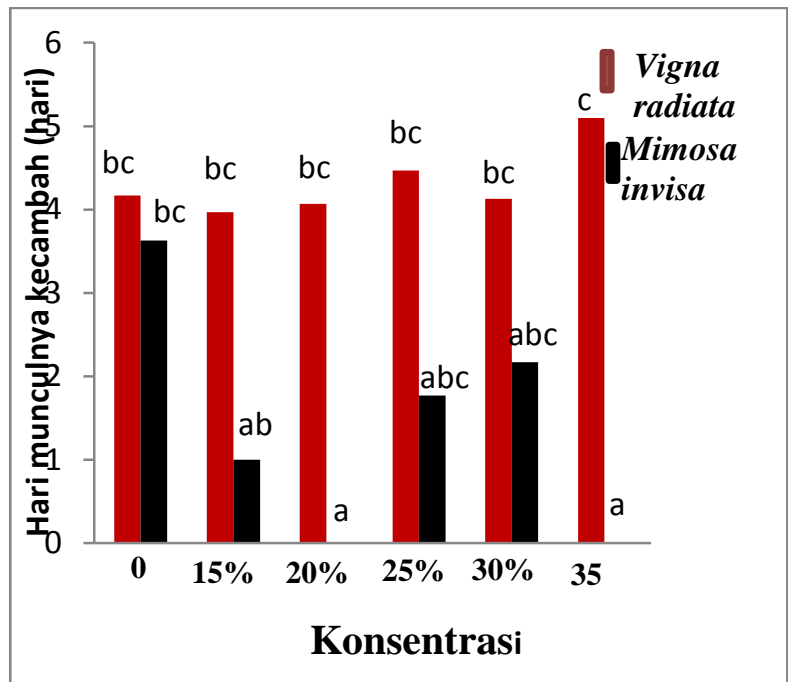

Gambar 2 Grafik data Hari munculnya kecambah V.radiata dan M.invisa 15 hari setelah tanam dengan konsentrasi ekstrak yang diberikan yaitu $0 \%\left(\mathrm{P}_{0}\right), 15 \%$ $\left(\mathrm{P}_{1}\right), 20 \%\left(\mathrm{P}_{2}\right), 50 \%\left(\mathrm{P}_{3}\right), 30 \%\left(\mathrm{P}_{4}\right)$ dan $35 \%\left(\mathrm{P}_{5}\right)$. Nilai yang ditunjukkan pada grafik adalah nilai rata-rata \pm standar deviasi.yang diikuti oleh huruf yang sama menunjukkan tidak berbeda nyata pada taraf uji 5\% (P $\geq$ $0,05)$.

\section{Panjang hipokotil}

Berdasarkan hasil analisis panjang hipokotil, menunjukan hasil yang tidak berbeda nyata $(\mathrm{P}=<0,05)$ bahwa pemberian ekstrak dapat mempengaruhi panjang hipokotil. Panjang hipokotil yang tertinggi pada tumbuhan kacang hijau (Vigna radiata )diperoleh pada pemberian
P0 dengan konsentrasi $0 \%$ (air) sebagai kontrol, berturut-turut yang terendah pada pemberian konsentrasi $35 \%$ sampai $15 \%$ dan biji (Mimosa invisa) di peroleh pada pemberian P0 dengan konsentrasi $0 \%$ (air) sebagai kontrol, berturut-turut yang terendah pada pemberian konsentrasi $30 \%$ sampai $15 \%$ ( Gambar 3).

\section{Berat basah}

Berdasarkan hasil analisis berat basah, menunjukan hasil yang tidak berbeda nyata $(\mathrm{P}=<0,05)$ bahwa pemberian ekstrak yang berbeda dapat mempengaruhi berat basah. Berat basah yang tertinggi di peroleh pada pemberian ekstrak dengan konsentrasi $0 \%$ (air) sebagai kontrol, berturut-turut sampai yang terendah pada pemberian konsentrasi $15 \%$ sampai 35\% ( Gambar 4).

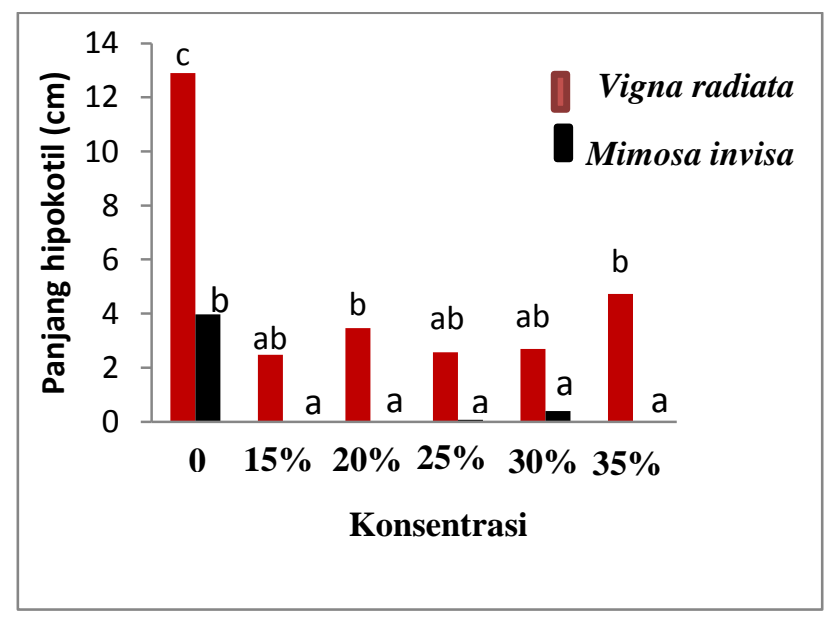

Gambar 3. Grafik data Panjang hipokotil V.radiata dan M.invisa 15 hari setelah tanam dengan konsentrasi ekstrak yang diberikan yaitu $0 \%\left(\mathrm{P}_{0}\right), 15 \%\left(\mathrm{P}_{1}\right), 20 \%$ $\left(\mathrm{P}_{2}\right), 50 \%\left(\mathrm{P}_{3}\right), 30 \%\left(\mathrm{P}_{4}\right)$ dan $35 \%\left(\mathrm{P}_{5}\right)$. Nilai yang ditunjukkan pada grafik adalah nilai rata-rata \pm standar deviasi.yang diikuti oleh huruf yang sama menunjukkan tidak berbeda nyata pada taraf uji $5 \%(\mathrm{P} \geq 0,05)$ 


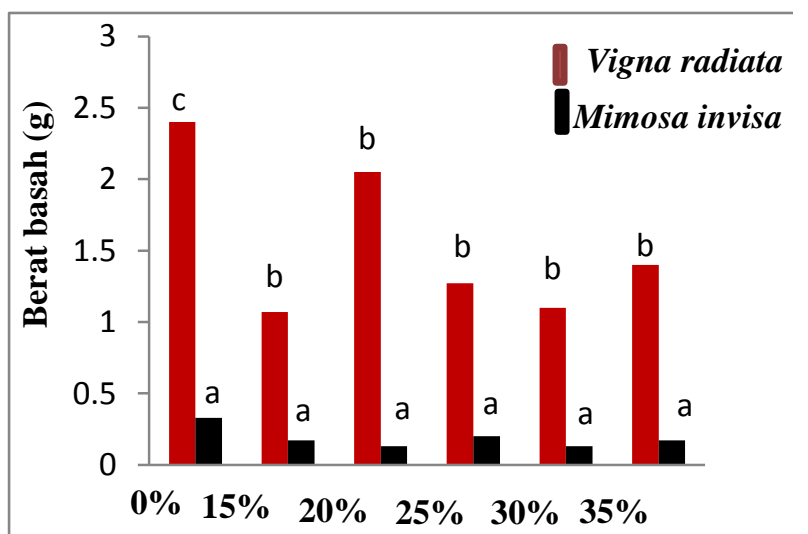

Konsentrasi

Gambar 4 Grafik berat basah perkecambahan $V$. radiata dan $M$. invisa 15 hari setelah tanam dengan konsentrasi ekstrak yang diberikan yaitu $0 \%$ $\left(\mathrm{P}_{0}\right), \quad 15 \%\left(\mathrm{P}_{1}\right), 20 \%\left(\mathrm{P}_{2}\right), 50 \%$ $\left(\mathrm{P}_{3}\right), 30 \%\left(\mathrm{P}_{4}\right)$ dan $35 \%\left(\mathrm{P}_{5}\right)$. Nilai yang ditunjukkan pada grafik adalah nilai rata-rata \pm standar deviasi. yang diikuti oleh huruf yang sama menunjukkan tidak berbeda nyata pada taraf uji 5\% (P $\geq 0,05$ )

\section{Pembahasan}

Hasil analisis data secara statistik menunjukan bahwa ada perbedaan perkecambahan tanaman Kacang hijau (Vigna radiata) dan biji gulma (Mimosa invisa) akibat pemberian berbagai konsentrasi ekstrak daun $C$. odorata. Perbedaan perkecambahan tersebut terdapat pada daya kecambah, laju perkecambahan, panjang hipokotil, dan berat basah.

Hasil penelitian menunjukan bahwa pemberian ekstrak $C$. odorata pada berbagai konsentrasi mempengaruhi daya kecambah pada gulma $M$. invisa, semakin tinggi konsentrasi $C$. odorata maka semakin menghambat munculnya perkecambahan, hal ini dapat di lihat pada gambar 1. Peningkatan konsentrasi ekstrak juga mengurangi persentase perkecambahan dan memperlambat perkecambahan biji gulma $M$. invisa sedangkan, pemberian ekstrak $C$. odorata terhadap perkecambahan tidak mempengaruhi daya kecambah biji $V$. radiata, hal ini terjadi karena adanya senyawa allelokemi pada ekstrak daun $C$. odorata yang bersifat selektif yaitu berpengaruh terhadap organisme tertentu namun tidak terhadap organisme lain. Hal tersebut sejalan dengan hasil penelitian sebelumnya yang di lakukan oleh Astutik dkk (2003), yang menyatakan bahwa pada senyawa fenol yang dihasilkan $P$. indica berpengaruh terhadap pertumbuhan gulma $P$. niruri dan tidak berpengaruh terhadap pertumbuhan $P$. radiatus, tidak menunjukan pengaruh penghambatan pada $V$.radiata karena faktor pertahanan dari $V$. radiata secara morfologi terhadap tekanan lingkungan.

\section{Penurunan} kemampuan perkecambahan biji gulma $M$. invisa karena adanya allelopati dalam ekstrak $C$. odorata, penghambatan perkecambahan merupakan pengaruh allelopati yang paling umum di ketahui. Menurut Molisch (1937), alelopati meliputi interaksi biokimiawi secara timbal balik, yaitu yang bersifat penghambatan maupun perangsangan antara semua jenis tumbuhan. Tiwari (2011) bahwa senyawa 
alelokemi berupa fenol dan flavonoid dapat menghambat aktivitas enzim selama proses perkecambahan yang menyebabkan perkecambahan menjadi terhambat sehingga persentase perkecambahan menjadi menurun.

Hasil penelitian pada Gambar 2 hari munculnya kecambah. Menunjukan bahwa Pemberian ekstrak $C$. odorata berpengaruh dalam menekan laju perkecambahan biji gulma $M$. invisa, hal ini karena morfologi M. invisa dalam merespon allelopati yang berasal dari ekstrak daun $C$. odorata yang memungkinkan berpengaruh terhadap zat tumbuh yaitu dari golongan fenol dan alkaloid yang mudah menghambat pertumbuhan. Sedangkan pemberian ekstrak terhadap perkecambahan tidak mempengaruhi laju perkecambahan pada biji $V$. radiata, hal ini di duga terjadi karena biji $V$. radiata yang tidak merespon allelopati pada ekstrak pada masa perkecambahan. Hal ini sesuai dengan penelitian sebelumnya yang menyatakan bahwa dari golongan fenol, terpenoid, alkaloid yang mudah menghambat pertumbuhan dari tumbuhan yang bersaing.

Kirinyuh C. odorata (L.) mempunyai alellopati yang mampu menunda perkecambahan, Berbagai senyawa di identifikasi bersifat allelopati berupa minyak atsiri, flavonoid, Alkaloid, Fenolik, Saponin, Tanin. Salah satu dari Senyawa tersebut terkandung dalam berbagai jenis tumbuhan termasuk tumbuhan kirinyuh (C. odorata (L.) (Sunarwidi, 1986). Setelah di lakukan skrining fitokimia Tumbuhan C.odorata terbukti memiliki senyawa alkaloid, fenolik, tanin, saponin, flafonoid.

Pada Gambar 3 panjang hipokotil menunujukan bahwa pemberian ekstrak $C$. odorata, dengan peningkatan konsentrasi ekstrak dapat menyebabkan terjadinya penurunan panjang hipokotil pada gulma kecambah $M$. invisa. selain itu, pemberian ekstrak $C$. odorata dengan berbagai konsentrasi, juga menyebabkan terjadinya kematian pada kecambah M. invisa. Hal ini disebabkan karena zat penghambat pada ekstrak mampu di serap atau masuk ke dalam biji $M$. invisa pada masa perkecambahan. Pada proses perkecambahan adanya faktor luar yaitu pengaruh allelopati yang dapat menghambat panjang hipokotil biji $M$. invisa. Penghambatan dan penurunan yang terjadi disebabkan oleh adanya senyawa alelopati di dalam ekstrak daun $C$. odorata. namun pemberian ekstrak $C$. odorata juga menghambat panjang hipokotil pada kecambah V.radiata hal ini terjadi karena biji $V$. radiata merespon allelopati pada ekstrak C. odorata.

Pebriani (2013) mengungkapkan bahwa beberapa senyawa alelokemi yang bersifat menghambat pembelahan sel, sehingga panjang hipokotil pada 
perkecambahan menjadi terhambat adalah flavonoid dan senyawa fenol. Selain itu, terhambatnya pembelahan dan pembesaran sel selanjutnya akan mempengaruhi pertumbuhan dan panjang hipokotil sehingga menjadi pendek dan kerdil.

Gejala umum yang ditimbulkan oleh pengaruh allelopati pada tanaman adalah terhambatnya perkecambahan biji tanaman. Saat perkecambahan biji, allelopati dapat mempengaruhi kerja enzim selain itu senyawa allelopati juga dapat mengakibatkan aktivitas enzim terhambat sehingga perkecambahan terhambat bahkan biji tidak mampu berkecambah. Selain itu penghambatan perkecambahan biji juga terjadi karena permeabilitas membran sel yang menurun, pembelahan dan pembesaran sel yang terhambat dan menurunnya kemampuan dalam penyerapan air dan hara (Susanti dkk, 2014).

Hasil penelitian pada Gambar 4 (Berat basah) pemberian ekstrak $C$. odorata pada berbagai konsentrasi juga berpengaruh pada berat basah kecambah biji gulma $M$. invisa di mana terlihat perbedaan yang signifikan dari masing-masing perlakuan ekstrak. pemberian ekstrak dengan berbagai tingkatan konsentrasi memberikan hasil yang efektif dalam menghambat berat basah gulma selain itu, pemberian ekstrak juga bepengaruh pada kematian perkecambahan yang mengakibatkan kurangnya atau terhambatnya berat basah pada kecambah, kematian biji gulma $M$. invisa umumnya terlihat pada minggu ke 2 setelah pemberian ekstrak. Senyawa alellopati yang terserap dapat menjadi racun (toksik) sehingga dapat menyebabkan tumbuhan layu dan mengalami kematian.

Anggrahini (2009) menyatakan bahwa layu pada tanaman disebabkan karena adanya pemberian ekstrak dan kelayuan muncul setelah pemberian ekstrak. Kandungan alelopati akan terakumulasi dalam sel dan bersifat racun yang dapat menjadikan sel-sel tidak elastis dan menghambat transpor ion terlarut melewati membran sel. Hambatan tersebut menyebabkan pertumbuhan tanaman menjadi abnormal dan jika peristiwa ini berlangsung terus menerus maka dapat menyebabkan kematian pada tanaman.

Begitu pula dengan pemberian ekstrak pada biji $V$. radiata juga berpengaruh terhadap berat basah akan tetapi perbedaannya terlihat cukup kecil akan tetapi, pada waktu pengamatan adanya gejala kerusakan terlihat pada minggu hari ke 7 setelah pemberian ekstrak .gejala kerusakan yang di timbulkan seperti kelayuan pada daun yang muncul ataupun keseluruhan pada tanaman atau terjadi klorosis . Klorosis adalah keadaan abnormal yang terjadi pada daun akibat kekurangan klorofil. Klorosis terjadi karena 
masuknya senyawa alelopat yang terkandung di dalam ekstrak daun $C$. odorata bersama air.

Menurut Sastroutomo (1991), Penghambatan penambahan berat basah terjadi karena terganggunya penyerapan air dan terhambatnya proses fotosintesis. Mekanisme penghambatan di awali pada membran sel dengan terjadinya kerusakan struktur membran oleh senyawa fenol.

Tiwari (2011) menyatakan bahwa allelopati yang menghambat pertumbuhan tanaman seperti jumlah daun dan tinggi tanaman kemudian akan menurunkan berat basah tanaman tersebut.

Sumber alelokemi yang memasuki agroekosistem bisa berasal dari tanaman budidaya, gulma atau mikroorganisme yang terlibat dalam dekomposisi Senyawa kimia dengan potensi alelopati terdapat nyata di semua jaringan tumbuhan termasuk daun, bunga, buah, batang, akar, rhizoma serta biji dan kadarnya bervariasi di antara organ tumbuhan karena dipengaruhi periode perkembanganorgan tumbuhan tersebut (Sastroutomo, 1990).

Allelopati suatu tanaman dapat mempengaruhi pertumbuhan dan perkembangan tanaman lain. Allelopati terjadi pada beberapa tanaman budidaya yang ditanam secara rotasi. Kacang hijau termasuk tanaman budidaya yang mempunyai aktivitas allelopati. Tanaman kacang hijau mengeluarkan metabolit yang merugikan pertumbuhan tanaman tanaman yang ditanam di area tanam yang sama pada periode berikutnya (Solichatun, 2000).

Hasil ekstraksi daun $C$. odorata yang menggunakan metode maserasi dengan pelarut etanol menunjukkan bahwa uji fitokimia ekstrak tersebut positif mengandung senyawa saponin, tanin, flavonoid, alkaloid dan fenolik. Penggunaan pelarut polar sering digunakan untuk ekstraksi simplisia, pelarut polar seperti etanol yang digunakan pada uji ekstraksi mampu menarik senyawasenyawa metabolit sekunder seperti alkaloid, saponin, komponen fenolik, karotenoid, dan tanin. (Harborne, 1987).

Hasil penelitian dapat di simpulkan bahwa adanya perbedaan pertumbuhan gulma $M$. invisa dan kacang hijau (Vigna radiata) akibat pemberian ekstrak daun kirinyuh ( $C$. odorata) pada konsentrasi yang berbeda. Hambatan perkecambahan pada gulma $M$. invisa lebih besar lebih besar di bandingkan dengan $V$. radiata.perlakuan ekstrak daun $C$. odorata juga dapat menurunkan perkecambahan serta meningkatkan presentasi kematian biji gulma $M$. invisa. penghambatan perkecambahan biji gulma $M$. invisa dan kacang hijau (Vigna radiata) di mulai dari konsentrasi $15 \%$ sampai $35 \%$. Hal ini juga di sebabkan karena daun $C$. odorata positif mengandung senyawa metabolit sekunder, 
yaitu Saponin, tanin, flafonoid, alkaloid, dan fenolik. Berdasarkan daya hambat yang di hasilkan maka daun $C$. odorata dapat dijadikan sebagai herbisida alami untuk menghambat pertumbuhan gulma.

\section{DAFTAR PUSTAKA}

Anggrahini, S. 2009. Pengaruh Lama Pengecambahan terhadap Kandungan $\alpha$-Tokoferol dan Senyawa Proksimat Kecambah Kacang Hijau (Phaseolus radiatus $L$.). Vol 1(1):17-19.

Apriyana, S., Fatonah, S., Silviana, F.2012, Pengaruh Alelopati Calopogonium mucunoides Desv. Terhadap Perkecambahan dan Pertumbuhan Anakan Gulma Asystasia gangetica (L.) T. Anderson. Biospecies. Vol 5(2): 5-11.

Asmaliyah, Etik, W. E., Fitri, S. W. Mulyadi, K., Utami. S., Yudhistira. 2010, Pengenalan Tumbuhan Penghasil Pestisida Nabati Dan Pemanfaatannya Secara Tradisional, Anggraeni, I. (editor). Kementrian Kehutanan. Palembang.

Astutik, A., Raharjo, dan Purnomo, T. 2003, Pengaruh Ekstrak Daun Beluntas Pluchea IndicaL. terhadap Pertumbuhan Gulma Meniran (Phyllanthus Niruri L.) dan Tanaman Kacang Hijau (Phaseolus RadiatusL.). Vol 1(1) Hal: 9-16

[Depkes] Departemen Kesehatan Republik Indonesia, 2000. Parameter Standar Umum Ekstrak Tumbuhan Obat, Edisi I, Direktorat Jendral POM, Jakarta.

Harborne, J., 1987. Metode Fitokimia: Penuntun Cara Moderen Menganalisis Tumbuhan. Padmawinata, $\mathrm{K}$ dan Soediro, I. (penerjemah). Niksolihin, S. (editor). Institut Teknologi Bandung. Bandung.

Molisch, H., 1937. Der Einfluss einer Pflanze auf die andere-Allelopathie. Jena: Fischer.

Pakaya, W. 2015, Analisis kadar flavonoid dari ekstrak metanol daun dan bunga tembelekan. Skripsi. Jurusan Pendidikan Kimia, Fakultas Matematika dan IPA, Universitas Negeri Gorontalo. Gorontalo.

Pebriani, R., dan Mukarlina, 2013, Potensi Ekstrak Daun Sembung Rambat (Mikania Micrantha H.B.K) Sebagai Bioherbisida Terhadap Gulma Maman Ungu (Cleome Rutidosperma D.C) Dan Rumput Bahia (Paspalum Notatum Flugge). Protobiont. Vol 2 (2): 32-38.

Ramyashree, M., Krishna Ram, H., and Shivabasavaiah., 2012, Ethnomedicinal value of Opuntia elatior fruits and its effects in mice, Online Jurnal of Natural Science, Vol.3(3): 331 - 340.

Resmi, M., 2011, Metode Penelitian Tanaman Obat, Widya Padjajaran, Antapani, Bandung.

Rukmana, R., 1997, Budidaya Kacang Hijau, dan Pasca Panen. Kanisius, Yogyakarta.

Sastroutomo, S. S., 1991, Ekologi Gulma, PT. Gramedia Pustaka Utama. Jakarta.

Solichatun, 2000, Alelopati Ekstrak Kacang Hijau (Vigna radiata ( L.)Wilczek ) terhadap Perkecambahan Kedelai (Glycine max Merr .)BioSmart Vol 2(2): 31-36.

Soerjani, M. 1993, Arah pengelolaan gulma 
di waktu mendatang dalam kaitannya dengan wawasan lingkungan, Konverensi VIII HIGI. Bandung.

Sunarwidi. 1986, Aktifitas alang-alang ( Imperata cylindrica) pada perkecambahan benih klaret, Buletin perkaretan Vol 3 (3) Hal: 74-77.

Suprapto.1993, Bertanam Kacang Hijau. Penebar Swadaya. Jakarta.

Susanti, A. T. A., Isda. N. M. Fatonah. S. 2014, Potensi Alelopati Ekstrak Daun Gleichenia Linearis (Burm.) Underw. Terhadap Perkecambahan Dan Pertumbuhan Anakan Gulma Mikania Micrantha (L.) Kunth. JOM FMIPA 1(2).

Sutopo, L. 2004, Teknologi Benih, PT. Raja Grafido Persada. Jakarta.

Tiwari, K., Kaur M., Kaur G., dan Kaur H. 2011, Phytochemical Screening and Extraction A Review, Internationale Pharmaceutica Sciencia vol. 1 (1): 16-20.

Tukey, J. 1953, The problem of multiple Comparisons, Unpublished Manuscript, Princeton University. 